\title{
Cosmopolitan Pluralism: Beyond the Cultural Turn ${ }^{1}$
}

\author{
Stephanie Lawson \\ Macquarie University
}

\begin{abstract}
The 'cultural turn' has had a profound influence across the humanities and social sciences in the last few decades, focusing on the extent to which specificity and particularity underpin what we can know, how we can know it, and how this affects our being-in-the world. It has been opposed, in particular, to universalist ideas, or at least those developed in European political and social thought. This has opened the way to a range of insights, from issues of pluralism and difference, both within political communities and between them, to the instability if not impossibility of foundations for knowledge. But because of the deep-seated opposition to virtually all forms of universalism implicit in the cultural turn, and which has therefore given it a strongly relativist dimension, it tends strongly to undermine cosmopolitan projects. This stems largely from the particular conceptualization of 'culture' that underpins projects associated with the cultural turn and which is derived mainly from the discipline of anthropology. Few studies embracing this 'cultural turn', however, have paid more than cursory attention to the culture concept itself, nor have its critics. This article suggests that conceptions of culture derived mainly from the discipline of anthropology have dominated overwhelmingly, while another important tradition of thought associated with the culture concept - namely the humanist tradition - has been either ignored or rejected. It argues further that we would do well to reconsider what humanist ideas can contribute to how 'culture' is both conceptualized and deployed in political thought and action, especially in countering the overparticularization of social and political phenomena that marks contemporary culturalist approaches and which have therefore tended to militate against cosmopolitan ideas. The article further suggests how we can shift from the strong relativist assumptions underpinning the cultural turn towards a conception of cosmopolitan pluralism that continues to value difference and particularity while remaining committed to a conception of humanity.
\end{abstract}

\section{Introduction}

Approaches to the study of virtually all of the humanities and social sciences, including my own discipline of politics and international relations, have been strongly influenced by the 'cultural turn' in recent years. Against the objective certainties supposedly produced by universally valid knowledge gleaned through the application of rigorous, scientifically grounded methodologies, the turn to culture has emphasized the particularities and specificities that underpin an irreducible plurality of knowledges and 'truths' possessed by people and communities located in different positions, places, hierarchies, times, spheres, structures, contexts and so on around the world. This has, at least according to its proponents, destabilized the very foundations on which conventional claims to knowledge and truth have long rested.

\footnotetext{
${ }^{1}$ This article is one product of an on-going project on 'cosmopolitan pluralism'. It draws on, and further develops, material which has appeared in the following previous publications: Lawson (2006), Lawson (2009) and Lawson (2011). I am grateful for the opportunity provided by the UTS Cosmopolitan Civil Societies group to present this paper at the 'Other Cosmopolitanisms' symposium, and also to the two anonymous referees for their helpful comments on the earlier version of this article.
} 
The same intellectual currents have seen the repudiation of anything that smacks of universal essences, especially that of an essential universal humanity and associated ideologies, including cosmopolitanism. One clear expression of these currents has been evident in the assertion of a 'cultural politics of difference' by those who, in the words of one contributor, have sought to 'trash the monolithic and homogeneous in the name of diversity, multiplicity, and heterogeneity; to reject the abstract, general and universal in light of the concrete, specific, and particular; and to historicize, contextualize, and pluralize by highlighting 'the contingent, provisional, variable, tentative, shifting, and changing.' (West 1993, p. 257). The implications are of course profound, especially in relation to matters such as human rights, democracy, conceptions of the good, and so on. And there is an enormous literature, especially with respect to the communitarian/cosmopolitan divide in normative theory, which reflects just how extensive and vigorous debates over such matters have been. We consider this divide in normative theory in due course.

Despite the apparent anti-essentialism of these broad intellectual currents, it seems that some forms of essentialism have flourished in culturalist approaches to the assertion of pluralism and difference. Indeed, to the extent that they depend on notions of essential Difference for their basic rationale, it may be said that 'culture' itself becomes the foundation. Certainly, this is the case with many 'culturalist' approaches to human rights taken by communitarian theorists, where it is commonly argued that different 'cultures' produce different conceptions of what 'rights' might attach to being human, or even of what it means to be 'human'. One familiar point is that most 'cultures', or at least those outside 'the West', have not produced their own authentic, autochthonous conceptualizations of the individual on which conceptions of universal human rights must ultimately rest. Rather, the latter is a conceptual development with a specificity and particularity anchored firmly within 'the West' - an entity which is also taken very much for granted - and must be contextualized accordingly. ${ }^{2}$

The purpose of this article is not to go over of familiar ground in debates over such matters of human rights and the merits and demerits of either culturalist or universalist approaches.

\footnotetext{
2 This is explicit in the famous statement published by the American Anthropological Association criticizing the notion of universal human rights set out in the UN's Universal Declaration and adopting an explicit cultural relativist position. See American Anthropological Association (1947, pp. 539-543). There have been significant changes in more recent years, however. While not giving up the concept of culture as something which differentiates human communities, the AAA now acknowledges the need for an approach which accommodates more universalist aspects of culture. See American Anthropological Association, (1999).
} 
There are criticisms to be made of both and, again, the literature is replete with such criticisms. The more immediate concern is with the extent to which many studies embracing the 'cultural turn' have paid little or no attention to the culture concept itself, simply invoking the language of cultural specificity and particularity without enquiring into just what these terms convey - apart from the fact that they position the author in opposition to some form of universality or cosmopolitanism. What is clear, however, is that the conceptualizations of culture that figure implicitly or explicitly in these debates, on both sides, are derived from the discipline of anthropology, often uncritically so. ${ }^{3}$

There is, however, another conception of culture which emerged at around much the same time as the anthropological version, and that is a humanist conception. Its subsequent career has been rather different and in many quarters it certainly does not seem to have enjoyed the same prestige. Indeed, some anthropologists have dismissed it as simply 'wrong'. I shall argue, though, that it may be fruitful to reconsider what humanist ideas have to contribute to the conceptualization of 'culture', especially in terms of serving as a counter to the overparticularization of social and political phenomena that has often been used to undermine cosmopolitan projects. This also accords with recent trends in more critical anthropological work, although these tend to avoid any mention of a humanist conception of culture as offering any useful insights.

This article, then, is largely concerned to put a case for a rethinking of the culture concept as an essential prerequisite to addressing an important intellectual problem facing the case for the reassertion of cosmopolitan ideas in the contemporary period - or for a 'cosmopolitan turn'. That problem is the enormously strong influence that anthropological conceptions have had on the idea of culture as manifest in the broad 'cultural turn', and which have given rise to what I call, for the sake of brevity, a 'culturalist' approach to a wide range of issues in social and political theory. ${ }^{4}$ This challenge to an entrenched 'culturalism', I suggest, is also essential to projects of 'methodological cosmopolitanism' which are attempting to transcend a long-established tradition of 'methodological nationalism' (see Beck and Sznaider 2006) and which I believe is directly comparable to the 'methodological particularism' which characterizes the cultural turn. The first substantive section looks in some detail at the

\footnotetext{
${ }^{3}$ Note that I use conceptions in the plural indicating that anthropology has produced a variety of definitions. ${ }^{4}$ This article could easily be filled with quotes and references demonstrating the enormity of this influence, leaving no space for anything else, so I must refer the reader instead to several previous works which set this out, especially in relation to political studies and historiography: See Lawson, 2006, Lawson 2009.
} 
emergence of both anthropological and humanist conceptions to illustrate the assumptions underpinning each of these, and therefore what 'culture' meant to those who first articulated it. Much of this may be well-known to historians of ideas, but it is not evident to me that it is known at all to many in the wider community of scholars who regularly make assumptions about the particularity of 'culture', in accord with the assumptions of the broad cultural turn, but rarely consider whether 'culture' can also be conceptualized in a way that transcends particularity and boundedness and which is therefore capable of supporting a 'cosmopolitan turn'.

\section{The Emergence of Culture Concepts}

The development of concepts of culture in Europe took place in the wake of an enormous expansion of knowledge in both social and natural spheres. This occurred as part of the move to mount critiques of social institutions within Europe, as well as the attempt to theorize a vast new array of facts about the world and its varying inhabitants which had been accumulating since long-range voyages of exploration began in the late fifteenth century. Before the late nineteenth century, 'culture' had been used in English mainly in agricultural terms for several centuries, reflecting its origins in the Latin cultura from the composite term agri cultura -cultivation of the soil. It also denoted training, fostering, and adornment as well as worship and cult (cultus). Later, it came to signify the cultivation of arts and letters and of the intellect more generally (Kahler 1968, p. 3). This was a distinctly humanist conception first articulated by Matthew Arnold in 1869. Embodied in intellectual, literary and artistic achievement transmitted from the past to the present, culture in Arnold's famous formulation referred to 'the best of what has been thought and said in the world' (Arnold 1963, p. 6). Thus, in the words of Terry Eagleton, the idea of 'culture' completed its journey 'from pigfarming to Picasso'. (quoted in Reeves 2004, p. 14).

But there was a parallel development in conceptualization taking place which incorporated everything from methods of swine-herding to artistic achievement, and which therefore seemed much more egalitarian and inclusive. While Matthew Arnold was setting in train the practice of cultural critique as a humanist enterprise, a British anthropologist, Edward B. Tylor, proposed another definition: 'Culture or Civilization, taken in its widest ethnographic sense, is that complex whole which includes knowledge, belief, art, morals, law, custom, and any other capabilities and habits acquired by man as a member of society’. (Tylor 1987, p. 37). This definition was to become one of the most widely cited in anthropological literature, 
appearing regularly in Anglophone textbooks and displayed prominently on the UNESCO website until at least 2006. ${ }^{5}$ By using 'culture' to denote a 'complex whole', Tylor was on the way to producing a reification, turning culture from a process - implied in the original idea of cultivation as well as in the humanist sense - into a thing in itself. ${ }^{6}$ But it was later anthropologists, especially the American school of cultural anthropology, who produced much more strongly reified versions, as we see shortly.

Tylor's anthropological approach is generally regarded as positive and descriptive rather than normative and evaluative, thereby placing it firmly within the realm of the scientific rather than the moral or aesthetic. It is partly for this reason that Arnold's conception on the one hand, and that of Tylor and subsequent anthropologists on the other, are often seen as in tension with each other. Certainly, Arnold's original conception is generally read (especially by anthropologists) as elitist, endorsing a notion of 'high culture', and not merely worthless in application to the concerns of anthropology, but ethically suspect too. Kroeber and Kluckhorn maintain that Arnold's conception, along with other humanist interpretations, is ethnocentric, absolutist, and disdainful of so-called 'low culture'. The anthropological attitude, in contrast, is relativistic, 'it assumes that every society through its culture seeks and in some measure finds values ... (Kroeber and Kluckhohn 1963, p. 61). One contemporary anthropologist, following this example, has said that if 'we want to retain the idea of culture as an analytic tool, we must begin by dismissing Arnold's construction of it'. (Avruch 1998, p. 9).

Arnold's liberal humanist ideas, however, were much more complex than simple assumptions about elitism convey. And if Arnold's notion of culture 'was universal in its moral scope and application, emerging from and directed towards what was distinctively human in humanity’ (Muhern 2000, p. xvi). then it shares some important common ground with anthropology which, after all, has also been concerned to delineate, through the concept of culture, that which is distinctively 'human'. Arnold was also concerned with the need to promote education so that people could become more critical of their own society. He was very much concerned with the 'cult of inequality' in Victorian society and its injustices. And if he was

\footnotetext{
${ }^{5}$ Until at least then, Tylor's definition was to be found at http://portal.unesco.org as the definition of culture, although it has since disappeared.

${ }^{6}$ There is much more to Tylor's formulation that there is space to discuss here, especially in the context of evolutionary ideas prevalent in his time which produced certain overlaps with the humanist approach. For further discussion see Stocking (1963, pp. 783-799).
} 
elitist, he was also scathing in his assessment of the so-called aristocracy which he saw as incapable of providing worthwhile leadership, such 'serenity' as they possessed coming not from a personal harmonization of ideas through the nurturing of culture, but from never having had any ideas to trouble them in the first place. (Johnson 1979, esp. pp. 19-24).

Arnold was therefore ultimately concerned with the role of culture and how it might be used to address social problems through critique. This was certainly different from the concerns of the anthropologists with so-called 'primitive' societies. But anthropologists, too, were concerned to say something about their own societies through the study of cultural phenomena in other places. More generally, the humanist approach places a strong emphasis on the relationship between culture and the development of shared values which contribute to social cohesion, and this is not dissimilar to anthropological concerns from Tylor's time to the present. These issues aside, although the earliest of the anthropological definitions of culture in English was decisive for seeing culture as a 'complex whole', thereby prefiguring the 'whole way of life' approach, Tylor did not quite articulate the concept of ' $a$ culture' which in turn implied a plurality of different 'cultures' as 'particular ways of life'. In the English speaking world, this step was to be taken more than twenty years later by the German-born Franz Boas, a key figure in American cultural anthropology (see Stocking 1992, p. 203). ${ }^{7}$

Boas began his career with a notion of culture framed by both humanist and evolutionary usages. Developments in his native Germany and Herder's important plural usage of the term, combined with his strong sense of the equal worth of all human communities and a concomitant rejection of any standard against which 'progress' might be measured, were decisive for his later work, and that of his students. Stocking notes that in their further development of the culture concept, and in keeping with their own normative purpose in demonstrating the intrinsic equality of all human communities and their distinctive practices as a counter to biological racism, the Boasian school promoted a more thoroughgoing sense of difference between such communities. This stamped American cultural anthropology with a strong commitment to the fundamental historicity of all cultural phenomena (Stocking 1992, p. 203).

\footnotetext{
${ }^{7}$ Note that Stocking, in all his reading of Tylor, found no instance of the use of the word culture in the plural, nor in Boas before 1895, and that it starts to appear regularly only in the first generation of Boas' students around 1910.
} 
Since that time, anthropological conceptions of culture have proliferated, but in the latter half of the twentieth century a hermeneutic or interpretive approach pioneered by Clifford Geertz became highly influential, and remains a touchstone for many anthropologists as well as for those working in cognate fields. Geertz's major work on The Interpretation of Cultures (1975) is notable, among other things, for leading the anthropological study of culture from explanation to the interpretation of meaning and 'thick description'. Geertz stated his belief in the idea of 'man' as an 'animal suspended in webs of significance he has spun for himself' with culture consisting in those webs. The analysis of culture, he said, is therefore 'not an experimental science in search of a law but an interpretive one in search of meaning.' (Geertz 1975, p. 5). This statement encapsulates the key intellectual standpoint of the cultural turn.

While the interpretive approach may have shifted anthropology's task from explanation to interpretation, it retained a heavy emphasis on culture as a marker of difference between human communities. It also retained strong elements of the cultural and ethical relativism evident in the Boasian approach. These were originally introduced for the purpose of defeating evolutionary conceptions of culture along with biological racism. However, to the extent that an anthropological conception of culture, rather than biological notions of race, has come to be used as a definitive marker of human difference, it now functions in much the same way that 'race' did in the past (see Lawson 2006) and is indeed implicated in contemporary expressions of racism, as we see later.

\section{Defining Culture in the Contemporary World}

By the mid-twentieth century, culture had become one of the most complex words in the English language, and open to numerous interpretations (Williams 1976). This was probably due at least partly to its strongly appraisive connotations. If a concept denotes something that is highly valued, as ‘culture' usually does, and if a great deal is claimed in its name (for example, that culture is the source of all moral values), then it is bound to provoke endless contestation among rival claimants over what it really means. At another level, there is a problem when culture shifts 'from something to be described, interpreted, and perhaps explained, and is treated instead as a source of explanation in itself.' (Kuper 2000, xi).

Let us look briefly at a number of different meanings attributed to 'culture' in the contemporary social and human sciences, conveniently summarized in a typology proposed 
by cultural theorists Glenn Jordan and Chris Weedon (1995, pp. 6-8), and which attempts to categorize the basic understandings that 'culture' has acquired over the last century or so.

1. Culture as 'a general process of intellectual, spiritual and aesthetic development'.

2. Culture as 'the works and practices of intellectual and especially artistic activity’ which generally covers ‘music, literature, painting and sculpture, theatre and film.’

3. Culture as a 'particular way of life' where culture cannot be reduced to any one individual but exists only as the property of a particular collective.

4. Culture as the signifying system through which a social order is communicated, reproduced, experienced and explored. Here culture is a dimension of virtually all economic, social and political institutions, and resides in 'a set of material practices which constitute meanings, values and subjectivities'.

The first approximates a humanist approach which denotes the ‘cultivation’ of individual mind and character, although it is implicit in anthropological approaches as well. The second was originally based on the older conception of 'high culture', but which has been expanded to include virtually all kinds of 'popular culture' and therefore need not carry elitist connotations. The third category denotes the existence of cultures in the plural which accords with common anthropological conceptions. The fourth is an all-encompassing category although the emphasis is clearly on dynamic processes. Jordan and Weedon also say that this conception takes two main forms: 'In its weaker dialectical form, it suggests that as human beings create culture, so culture creates them'. In a stronger version, influenced by structuralist and poststructuralist theory, culture is the determinant of subjectivity (ibid).

This latter point begs the rather significant question of who has the authoritative resources to create or interpret 'the culture' that in turn creates subjectivities. It also alerts us to the rather important matter of the relationship between culture and power which theorists such as Gramsci and Foucault have been concerned to expose. Gramsci in particular has highlighted the extent to which those with the power to interpret culture for, or on behalf of, the society in question not only do so to their own advantage, but make it seem natural and right, thus 
producing the conditions for hegemonic control (see Gramsci 1967). Foucault developed similar ideas about the way in which 'regimes of truth' are imposed through powerful discourses (Foucault 1980, p. 3).

Neither, however, could be said to be working within a traditional anthropological understanding of 'culture' which has often been concerned less with the critique of power relations within 'cultural groups' than with using the concept to differentiate one group from another, and more generally to delineate between the 'West' - or 'Western culture' - and non-Western others (see Lawson 2006, esp. Ch. 8). Certainly, part of this exercise may involve explaining how power operates within different cultural groups. But the aim has not, at least conventionally, been to critique them - especially if the group in question is 'nonWestern’. Indeed, (Western) anthropology’s ethos has for a very long time been strongly averse to engaging in critiques of non-Western 'others'. This is at least partly because contemporary anthropology, having distanced itself from its previous close associations with colonialism, has become a leading exponent of anti-Eurocentrism centrism (but not necessarily of ethnocentrism per se) and can scarcely engage in such critiques without running foul of some of its own normative presuppositions.

What resources then, can critiques of power that transcend the putative boundaries imposed by (cultural) anthropology draw on? This is an important question for any project of critical cosmopolitanism. I suggest that we might well look to alternative constructions of cultural theory that trace their lineage through a humanist tradition and which are conceived as a source of critique. To do so, however, is to go very much against a highly influential trend in the academy which has seen a distinct 'anti-humanist orthodoxy' holding sway for some time (Good 2001, p. 6). At the same time, this orthodoxy has been instrumental in promoting the reification and glorification of group identity - whether on the basis of race, colour, gender, class, religion, nation, linguistic community or any number of other categories which have emerged as manifestations of group essentialism, strenuously opposed to universalist essentialism. $^{8}$

\footnotetext{
8 There are some interesting ideas about 'strategic essentialism' which emerge from Gayatri Chakravorty Spivak's work in which she effectively argues for the political necessity of invoking group essentialism - for example, in the pursuit of feminist causes (Spivak 1993). There is no reason, however, why an equally
} 
This approach may be called 'culturalism', a term which for present purposes captures the general mind-set characteristic of the ‘cultural turn' in the human sciences and which stands opposed to universalizing tendencies, or at least those emanating from Europe or 'the West'. But for all the scathing critiques that culturalists have mounted of the 'Eurocentric mind' and its construction of 'others', culturalism depends above all on the construction of otherness, and very often with strong exoticist underpinnings. For without group identities based on a differentiating concept such as 'culture', we can scarcely have the category of 'other' at all. I next consider the concept of culture more specifically in relation to humanism, looking at both critiques of humanism as well as more supportive observations and arguments.

\section{Culture and Humanism}

The currency of the word 'humanism' in Arnold's time was almost as recent as that of the word 'culture' (at least in anything much more than an agricultural sense). But as with 'culture', 'humanism' emerged as a short-hand for a complex of ideas associated with the Renaissance (another nineteenth century term) that coalesced around the notion of 'an essential humanity unconditioned by time, place or circumstance', something that is 'everywhere and always the same' and which contains an inherent rationality and dignity independent of particular theological underpinnings (Davies 2008, p. 24). In terms of today’s culturalist parlance, such a view would be denounced as a wholly untenable universalist 'pretension' or 'conceit'; one which is tainted at its core not just with any old form of ethnocentrism but a supremely distasteful and arrogant form - Eurocentrism; imbued with a laughable if not pathetic faith in reason and dressing up its gross subjectivities in the garb of objectivity through which it masquerades as the touchstone of 'the good' for all people(s).

All these crimes of humanist thought are seen as typical of nineteenth century liberal ideas, and certainly quite specific to the European historical/cultural context in which they arose. Indeed, Tony Davies says that the idea of an essential humanity is a 'nineteenth century anachronism', one which remains 'deeply ingrained in contemporary self-consciousness and everyday common sense, so deeply that it requires a conscious effort, every time someone appeals to 'human nature' or the 'human condition', to recall how recent such notions are, work (see especially Gilroy 2000). But for an interesting critique of Gilroy see Robotham (2005). 
how specific to a particular history, location and point of view, and how very odd it would seem, in cultures historically or ethnologically unlike our own, to separate out and privilege 'Man' in this way.' (ibid., p. 25). Davies' claim, the language in which it is couched (including the epithet 'anachronism'), and the assumptions on which it is based, constitute an exemplar of 'cultural turnism'.

The irony is that in making this claim, Davies uses as a foil an anthropological notion of 'culture' (and hence 'cultures') based on an idea of particularity and specificity that is itself, according to his own logic irrevocably tied to a particular time and place, having also arisen in the late nineteenth century in response to certain developments then. But there is no conscious effort made to recall this. Nor is there any consideration of a broad history of ideas which turns up cognate ideas about 'humanity' and 'human nature' in other times and other places. Let us take, for example, Thucydides’ preface to his famous text which clearly expresses the hope that his account of the Peloponnesian War may be judged useful to those wishing to understand the past since, human nature being what it is, similar events are bound to occur again (Thucydides 1972, I, 48). Stoic thought in both the Greek and Roman worlds was steeped in notions of an essential humanity. Well before Thucydides and the Stoics, and on the other side of the Eurasian continent, Confucian humanism emphasized the link between virtue and humanity attained only by a process of cultivation (see, generally, Tu 1998; Cua 1991). Interestingly, a contemporary movement in China calls for a version of new humanism specifically to counter the 'New Liberalist' logic of global capitalism which purports to value human freedom, but which is committed only to the freedom of capitalism (Li 2008). Another version of humanism has been found in the medieval Islamic world of scholarship and learning where openness to new ideas also saw cultivation of the intellect as a valued activity (Goodman 2003). This does not mean that all humanist ideas are the same. Their expression in different times and places would certainly resonate with local, contextual factors giving rise to many variations on the common themes. Even so, these brief examples make a nonsense of claims about the (European) specificity and particularity of ideas to do with human nature and humanity as universal categories.

Another obvious counter to the claim that humanism is merely a $19^{\text {th }}$ century anachronism with a specificity rooted in the particularities of that time is the fact that although the word may not have been in common usage before then, the emergence of ideas underpinning the concept in European political and social thought spanned several centuries, beginning with 
the Renaissance and achieving pride of place in Enlightenment thought (Feher 1991, p. 183). Indeed, 'a new, self-consciously critical attitude toward prevailing cultural practices and institutions' (ibid., emphasis added) is often regarded as the defining characteristic of the Enlightenment. Ever since then, however, it seems that humanism has itself been under attack from almost every other critical discourse (Surber 1998, p. 24). In the contemporary period, Ferenc Feher argues that humanism is the main target of deconstructive philosophical criticism on several related grounds. First, it positions 'Man' as ‘the philosophical axis of world interpretation'. Second, it functions as an oppressive universal, largely because this humanist 'Man' is actually 'identical with the European man who embarked on the project of remaking the world in the image of the only progressive arrangement he was familiar with as well as prepared to recognize: nineteenth-century Europe', a scenario which forcibly blended all differences or persecuted, and sometimes exterminated, those who could not or would not be assimilated. It is therefore not merely ethnocentric in a peculiarly European way, it is also regarded as racist (ibid., pp. 184-85).

Or so the story goes. But as Feher further notes, key liberal humanist figures such as Kant actually opposed colonization, believing that those who purported to be civilizing the primitives through such means were acting out a 'shameful parody of the Enlightenment.' For Kant, emancipation could only be achieved through one's own deeds or self-tutelage (i.e., self-cultivation), and could not be imposed by others (ibid., p. 184), while for Arnold, the true barbarians were the English aristocracy. In addition, it is hard to see how a set of ideas supporting the unity of humankind can be branded as racist by those seeking the conceptual separation of the species on the basis of a thoroughgoing cultural determinism which is every bit as insidious as the biological determinism that underpinned European racism of the nineteenth century and which it purportedly displaced.

More generally, if humanism - of whatever variety - places an excessive emphasis on individualism within a universalistic framework, it is no less a problem than any theory that places an excessive emphasis on groupism, of whatever variety. The question is how we can construct a viable theory of culture that is not positioned firmly on one side or another of the dichotomy and which can support a viable cosmopolitan project that recognizes both the particular and the universal. In approaching this question, we look again at the relationship between culture, identity and political community and a possible way out of the ontological either/or trap. 


\section{From Cultural Relativism to Cosmopolitan Pluralism}

Although both universalist and relativist approaches have tendencies to absolutism, each mode makes an essential contribution to normative theory in that we need to take account of both the general and the particular, of sameness and difference. We may well see 'otherness' as constituted by difference, but this does not mean that we cannot also see the self in the other. This suggests the need for a pluralist synthesis attuned to the realities of human existence, and co-existence, and the multiplicity of experiences, values, interests and needs that subsist not only between groups and collectivities but within them as well, for the tendency to homogenize insiders as much as outsiders - a strong tendency in communitarian theory - creates other kinds of problems. It also suggests that we need to move away from dichotomous thinking towards more of a dialectic mode, enabling an ongoing conversation rather than closure around one or other of the oppositions. Let us consider this in relation to the cosmopolitan/communitarian divide in normative theory.

In strongly culturalist versions of communitarianism, the community is generally defined by 'its culture' which includes its own particular moral universe. The normative thrust of communitarianism therefore tends to relativism (in a cultural sense) and to the adoption of an oppositional stance against cosmopolitan claims about universal moral principles. ${ }^{9}$ For a communitarian, the notion of the 'community of humankind' is practically an oxymoron since communities are by definition a discrete portion of the whole. In contrast, cosmopolitanism transcends, but does not negate, the local and affirms the validity of certain universalist principles in such matters as basic human rights. This does not necessarily settle what is 'basic' in the way of rights and what is secondary or supplementary, but it provides a minimum framework for universalist claims.

Neither approach need lead to a form of absolutism, either by denying the relevance of the social or cultural world(s) in which humans actually live their lives or by insisting on such a radical incommensurability of unique cultural worlds that a notion of common humanity becomes impossible. But without some concessions to pluralism from a universalist perspective, or to minimum standards of moral behaviour from a more relativist one, both do tend strongly towards absolutism. To preserve what is valuable in the concept of culture from

\footnotetext{
9 At least one communitarian rejects cultural relativism as an obstacle to creating moral dialogues across national lines which may in turn provide a source for global moral principles (see Etzioni 1997).
} 
cultural absolutism conceived in either particularist or universalist terms, a different approach is needed.

In the space between the opposing poles of virtually any dichotomy it is possible to construct a middle ground. In terms of the present discussion, that ground is essentially pluralist.

Because it stands for 'the many' rather 'the one' - pluralism is sometimes mistakenly equated with relativism. But as one leading scholar of global politics notes, an 'engaged pluralism' recognizes that although concrete phenomena are susceptible to competing explanations, this does not equate to an 'anything goes' approach nor does it mean that in the absence of true foundational standards, no standards are possible at all. (Kratochwil 2003, p. 126).

With respect to culture and normative theory there is, in practice, a middle ground on a range of issues that is essential to avoiding the repugnant consequences of absolutist forms of both universalism and relativism. Few communitarians would support the custom of human sacrifice, even if it was endorsed by the 'cultural community' within which it was practiced. And it is hard to imagine that any would want to claim that the death camps of Nazi Germany could be justified by reference to the unique moral universe of Nazism. On the other hand, universalists would be hard put to justify one, and only one, vision of 'the good' universally applicable across time and space, especially when it comes to deciding who has the authority to define 'the good' and impose it on others. Due attention to the plurality of values that emerge in different settings must therefore play a part in any viable normative theory alongside more general principles. Radical approaches to either universalism or relativism, by attempting to provide clear and unambiguous positions, lead only to dogmatism and closure around a rigid dichotomy.

In contrast with either form of absolutism, pluralism does not provide a site from which definitive answers can always be delivered. It is better characterized as an untidy meeting place of contesting ideas, lacking firm foundations for certainties (such as those delivered from the opposing poles), where boundaries (such as they are) remain fuzzy, and where cutoff points for tolerance of this or that practice always require a measure of judgment according to both context and general principles. A normative position based on this approach is best described as cosmopolitan pluralism. It is cosmopolitan in its breadth, because it incorporates humanity as a whole, but pluralistic in character because it both acknowledges and values the diversity within it. It lies between the conventional 
understandings of a rigid universalism requiring uniformity on the one hand, and an incoherent relativism on the other, and repudiates the dogmatic elements that characterize both. Above all, it is dynamic, allowing for the contingent as opposed to the absolute, and acknowledging 'culture’ as endlessly shifting and changing, and certainly never fixed permanently in any particular shape or form. It is capable of recognizing the importance of specific, local circumstances and socializing influences on individual human development while refusing to accept culturally determined outcomes. It does not rely on an evolutionary notion of progress suggested by traditional liberal philosophy, but neither does it preclude the possibility of making life better for those whose lives are blighted by poverty, violence, and injustice.

\section{Reconceptualizing Culture in the 'Cosmopolitan Turn'}

Anthropological conceptualizations of culture have helped to generate many insights about the value of difference and have served as an important counter to ethnocentricity especially of the 'Euro' variety. They have also contributed to insights concerning the problems and pitfalls of asserting universalist notions of 'the good' in the face of competing conceptions derived from different social contexts. In the process, however, the dangers of homogenization implicit in universalist conceptions of the good have sometimes simply been transferred to the partial entities known as 'cultures' which themselves may contain a plurality of interests as well as conceptions of the good, often emanating from differential placement in hierarchies of power. The notion of culture as always denoting difference has its problems as well, for culture understood in this way tends to diminish dynamic properties in favour of those which are fixed and timeless - thus constituting localized essences.

Contemporary anthropologists are now among those who endorse a more dynamic approach to avoid such problems. The following quotations illustrate a number of difficulties that anthropologists have identified in relation to their 'master concept' and which are directly relevant to the concerns of this article:

Cultural relativism provides an inaccurate set of descriptions of moral pluralism since it wields a misguided conception of culture. ... [cultural relativists] seem to hold to a nineteenth-century notion of culture as discrete and homogeneous ... Their relativism is predicated upon bounded conceptions of linguistic and cultural systems, but it falls apart in 
contexts of hybridity, creolisation, intermixture and the overlapping of political traditions. (Wilson 1997, p. 9).

Another provides a similar critique of the discipline's emphasis on difference:

Culture is used selectively for that which seems most salient to the outsider, namely difference. ... [it] is used increasingly in public debate to define an arena for contesting discourses on "identity". Under current conditions, such discourses provide an extremely fertile field for political entrepreneurship; they allow leaders and spokesmen to claim they are speaking on behalf of others; they allow the manipulation of media access; and they encourage the strategic construction of polarizing debates that translate into battles of influence. Such battles create hegemony and reduce options; they disempower followers and reduce the diversity of voices. (Barth 1995, p. 65).

Another powerful argument is that the anthropological replacement of biological difference with cultural difference has simply returned racism to its point of departure since it asserts, once again, 'the absolute, impenetrable, untranslatable character of different ways of being.'(Finkielkraut 1995, pp. 77, 80). On this view, cultural relativism joined with an insider/outsider dichotomy represents not the denial of racist categories of human difference, but rather their reaffirmation under a new banner. Stewart Hall also observes that biological racism and cultural differentialism constitute not two separate (and opposed) systems but rather two registers of racism (quoted in Moore, Pandian \& Kosek 2003, p. 27) while anthropologist Adam Kuper notes that contemporary cultural anthropologists repudiate the popular notion that differences are 'natural', but goes on to point out that 'a rhetoric that places great emphasis on difference and identity is not best placed to counter these views.' Indeed, the insistence that radical differences can be observed between peoples serves to sustain them (Kuper 2000, pp. 239-40).

What emerges from these various critiques of the culture concept ${ }^{10}$ is that its conceptualization needs to give more prominence to its dynamic properties, especially in terms of the fact that change and transformation takes place through something called culture. The culture concept therefore requires restating as a highly complex and contingent process rather than an objective, concrete 'thing' that defines the foundations for political

\footnotetext{
${ }^{10}$ There are highly relevant critiques from other disciplines as well which there is insufficient space to explore. For one insightful contribution from human geography see Mitchell (1995 pp. 102-116).
} 
communities and/or values systems, and certainly not a thing that possesses people. As a process which is continuous, 'culture' leads neither to a final endpoint, nor is it to be equated with 'progress'. In other words, cultural change can obviously lead to both negative and positive outcomes and therefore has no necessary telos. From a humanist and cosmopolitan perspective, however, there is always a prospect that things can be changed for the better and that critical intellectual engagement is essential to the task.

For any form of study that deals with relationships between groups it is imperative to understand that the capacity to interact with other humans, whether they are members of our own or other communities, lies in the dynamics of culture itself. Cultural differences between individuals and communities notwithstanding, the fact that we are cultural creatures in the first place implies the ability to learn to navigate around new and different situations and to extend the capacity for inter-subjective communication well beyond one's own immediate social, cultural and political contexts to a cosmopolitan one. Viewed in this way, it is not 'culture' that throws up barriers to understanding and interaction, as assumed in notions of 'cultural incommensurability', but 'culture' that actually enables the barriers to be broken down. This resonates with the imagining of open social spaces, or 'world openness' as envisaged by proponents of a new 'critical cosmopolitanism' such as Gerard Delanty, who also see culture 'as an on-going process of construction as opposed to being embodied in a particular way of life' (Delanty 2006, p. 31).

\section{Conclusion}

Students of the humanities and social sciences are called on to deal with a highly pluralistic world in which both similarities and differences abound within local, national, regional and global spheres. It is commonsense to adopt an approach that is sensitive to cultural, historical and other contextual factors. This is good practice from both a methodological and normative point of view, leading to informed interpretation and explanation.

In an increasingly globalized world, however, it is impossible not to make value judgements about problems and issues in locations other than our 'own' national or cultural spaces. The real problem for the study of politics and international relations, and for any other disciplines or fields of study which have to engage with issues that cross any kind of putative cultural boundary is not how to avoid making value judgements about those who occupy what may 
seem to be a different set of subjectivities, but how to make value judgements that are wellinformed, reflexive and which take into account of both general principles about the human condition as well as the particularities of any given context.

A viable project of critical cosmopolitanism, which incorporates pluralism as a key feature of human existence, requires redescribing culture as a highly complex and contingent process rather than an objective, concrete 'thing' that defines the foundations for particularistic communities. In practical terms, this means the promotion of shared cultural norms at a global level in the interest of enhancing humanitarian principles and practices, and to which a robust conceptualization of humanity is also central. It is worth emphasizing again, however, that this by no means suggests that we dispense with the insights of anthropology. Rather, I wish to emphasize the extent to which particularist (anthropological) and universalist (humanist) approaches both have something to offer in the continuing project of conceptualizing 'culture' in a world which is likely to remain irredeemably pluralistic while also becoming increasingly cosmopolitan ${ }^{11}$.

\section{References}

American Anthropological Association, Executive Board 1947, 'Statement on Human Rights’ American Anthropologist, vol. 49, no. 4, pp. 539-543.

American Anthropological Association, Committee on Human Rights 1999, 'Declaration on Anthropology and Human Rights’, adopted June 1999. www.aaanet.org/stmts/humanrts.htm accessed 23/8/2011.

Arnold, M. 1963, Culture and Anarchy, ed. J. Dover Wilson, Cambridge University Press, Cambridge.

Avruch, K. 1998, Culture and Conflict Resolution, United States Institute of Peace Press, Washington DC.

Barth, F. 1995, 'Other Knowledge and Other Ways of Knowing', Journal of Anthropological Research, vol. 51, no. 1, pp. 65-68.

Chomsky, N. 1999, The New Military Humanism: Lessons from Kosovo, Pluto Press, London.

Beck, Ulrich and N. Szaider 2006, 'Unpacking Cosmopolitanism for the Social Sciences: A Research Agenda’, British Journal of Sociology, vol. 57, issue 1, pp. 1-23.

Cua, A. 1991, 'Challenges and Preconditions of Adjudication' in E. Deutsch (ed), Culture and Modernity: East-West Philosophical Perspectives, University of Hawai’i Press, Honolulu, pp. 279-298.

\footnotetext{
${ }^{11}$ For a recent study of culture and international relations which also argues for greater attention to the humanist conception of culture see Reeves (2004).
} 
Davies, T. 2008, Humanism, $2^{\text {nd }}$ edn, Routledge, London.

Delanty, G 2006, 'The Cosmopolitan Imagination: Critical Cosmopolitanism and Social Theory', British Journal of Sociology, vol. 57, issue 1, pp. 25-47.

Etzioni, A. 1997, 'The End of Cross-Cultural Relativism', Alternatives, vol. 22, no. 2, pp. 177-189.

Escobar, A. 1993, 'The Limits of Reflexivity: Politics in Anthropology’s Post-Writing Culture Era', Journal of Anthropological Research, vol. 49, no. 4, pp. 377-391.

Feher, F. 1991, 'Between Relativism and Fundamentalism: Hermeneutics as Europe's Mainstream Political and Moral Tradition' in E. Deutsch (ed), Culture and Modernity: East-West Philosophical Perspectives, University of Hawai'i Press, Honolulu. Finkielkraut, A. 1995, The Defeat of the Mind, Columbia University Press, New York.

Foucault, M. 1980, Power/Knowledge: Selected Interviews and Other Writings, ed. and transl. C. Gordon, Harvester Press, Brighton UK.

Geertz, C. 1975, The Interpretation of Cultures, Hutchinson, London.

Gilroy, P. 2005, ‘A New Cosmopolitanism’, Interventions, vol. 7, no. 3, pp. 287-292.

Gilroy, P. 2000, Against Race: Imagining Political Culture Beyond the Color Line, Harvard University Press, Cambridge, MA.

Good, G. 2001, Humanism Betrayed: Theory, Ideology and Culture in the Contemporary University, McGill-Queen’s University Press, Montreal and Kingston.

Goodman, L. 2003, Islamic Humanism, Oxford University Press, Oxford.

Gramsci, A. 1967, The Modern Prince, and Other Writings, International Publishers, New York.

Johnson, L. 1979, The Cultural Critics: From Matthew Arnold to Raymond Williams, Routledge \& Kegan Paul, London.

Jordan, G and Weedon, C. 1995, Cultural Politics: Class, Gender and Race in the Postmodern World, Blackwell, Oxford.

Kahler, E. 1968, 'Culture and Evolution’ in M.F.A. Montagu (ed), Culture: Man's Adaptive Dimension, Oxford University Press, New York.

Kratochwil, F. 2003, 'The Monologue of “Science”', International Studies Review, vol. 5, no. 1, pp. 124-128.

Kroeber, A.L. and Kluckhohn, C. 1963, Culture: A Critical Review of Concepts and Definitions, Vintage Books, New York.

Kuper, A. 2000, Culture: The Anthropologists’ Account, Harvard University Press, Cambridge MA.

Moore, D., Pandian, A. and Kosek, J. 2003, 'Introduction: The Cultural Politics of Race and Nature: Terrains of Power and Practice' in D. Moore, J. Kosek and A. Pandian (eds), Race, Nature and the Politics of Difference, Duke University Press, Durham NC.

Li T. 2008, 'New Humanism', Modern Language Quarterly, vol. 69, no. 1, pp. 61-79.

Lawson, S. 2006, Culture and Context in World Politics, Palgrave Macmillan, Basingstoke, UK.

Lawson, S. 2008, 'Political Studies and the Contextual Turn: A Normative/ Methodological Critique’, Political Studies, vol. 56, no. 3, pp. 584-603.

Lawson, S. 2009, 'Reconceptualizing "Culture” in Political Studies: Beyond the Cultural Turn', presented at the annual conference of the Australian Political Studies 
Association, Macquarie University, Sydney, 27-30 September, 17 pp.

http://www.pol.mq.edu.au/apsa/papers/Refereed\%20papers/Lawson.pdf

Lawson, S. 2011, 'Nationalism and the Politics of Culture in a Globalizing World' in D.

Halikiopolou and S. Vasilopolou (eds), Nationalism and Globalisation, Routledge, Abingdon, UK.

Mitchell, D. 1995, 'There's No Such Thing as Culture: Towards a Reconceptualization of the Idea of Culture in Geography', Transactions of the Institute of British Geographers, New Series, vol. 20, no. 1, pp. 102-116.

Mulhern, F. 2000, Culture/Metaculture, Routledge, London.

Reeves, J. 2004, Culture and International Relations, Routledge, London.

Robotham, D. 2005, 'Cosmopolitanism and Planetary Humanism: The Strategic

Universalism of Paul Gilroy, South Atlantic Quarterly, vol. 104, no. 3, pp. 561-582.

Spivak, G 1993, Outside in the Teaching Machine, Routledge, London.

Stocking, G. 1963, 'Mathew Arnold, E.B. Tylor, and the Uses of Invention', American Anthropologist, vol. 65, no. 4, pp. 783-799.

Stocking, G. 1992, Race, Culture, and Evolution: Essays in the History of Anthropology, University of Chicago Press, Chicago.

Surber, J. 1998, Culture and Critique: An Introduction to the Critical Discourses of Cultural Studies, Westview, Boulder.

Thucydides 1972, History of the Peloponnesian War. Penguin, London.

Tu W. 1998, Humanity and Self-Cultivation: Essays in Confucian Thought, Cheng \& Tsui Co., Boston MA.

Tylor, E. 1987, 'The Science of Culture', reproduced in H. Applebaum (ed.), Perspectives in Cultural Anthropology, State University of New York, Albany NY.

West, C. 1993, 'The New Cultural Politics of Difference' in S. During (ed.), The Cultural Studies Reader, Routledge, London.

Williams, R. 1976, Keywords, London, Fontana.

Wilson, R. 1997, Human Rights, Culture and Context: Anthropological Perspectives, Pluto Press, London. 